\title{
Changing Water Quality in the Middle Mahakam Lakes: Water Quality Trends in a Context of Rapid Deforestation, Mining and Palm Oil Plantation Development in Indonesia's Middle Mahakam Wetlands
}

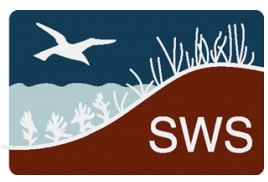

\author{
Edwin B.P. de Jong ${ }^{1}$ - Ad M. J. Ragas ${ }^{2} \cdot$ Gerben Nooteboom $^{3}$ • M. Mursidi ${ }^{4}$
}

Received: 10 November 2014 / Accepted: 14 May 2015 /Published online: 11 June 2015

(C) The Author(s) 2015. This article is published with open access at Springerlink.com

\begin{abstract}
The degradation of Indonesia's wetlands is continuing at a rapid pace. People living in the Middle Mahakam Lakes (MML) region, part of a major wetland area in Indonesia, have observed various negative changes in their local environment, especially with regard to water quality. We verify these local perceptions with the support of water quality measurements (physical and chemical) taken in 1992-93, 1995, 1998 and 2006. We also aim to present data that can be used to determine future trends. We evaluated the water quality of the MML by comparing the 2006 measurements with data reported for similar water systems in Kalimantan and with water quality standards in the USA, and set by the World Bank, Australia, Malaysia and South Africa. Measurements show that the water quality of the MML improved considerably between 1998 and 2006 but there seems to be a delicate balance between the $\mathrm{pH}$ value and the levels of oxygen, nutrients and hydrogen sulphide. The low alkalinity values indicate that the system is prone to $\mathrm{pH}$ changes, which could be triggered by an increased input of acids, as a consequence of deforestation, mining activities or the drainage of peat lands, effects already occurring in one of the lakes.
\end{abstract}

Keywords Water quality $\cdot$ Wetlands $\cdot$ Lakes $\cdot$ Sustainability Ecological status $\cdot$ Deforestation

Edwin B.P. de Jong

e.dejong@maw.ru.nl

Radboud University Nijmegen, Nijmegen, Netherlands

2 Radboud University Nijmegen, Nijmegen/Open Universiteit, Heerlen, Netherlands

3 University of Amsterdam, Amsterdam, Netherlands

4 Mulawarman University, Samarinda, Indonesia

\section{Introduction}

Indonesia's wetlands are a vital link in the water cycle, form a critical component of the global carbon cycle by storing peat, and have important functions and values in terms of water management and biodiversity conservation (Rieley et al. 1997; Shephard et al. 1997; Hooijer et al. 2006; Chokkalingam et al. 2009). In addition, they provide the basis for many livelihoods, such as those based on fisheries or agriculture and forestry products (Giesen and Sukotjo 1991; MacKinnon et al. 1996). Notwithstanding the high ecological and economic values of the wetlands, the loss and degradation of wetlands is continuing at a rapid pace. Of the 54 million ha of wetlands once present in Indonesia, only 40 million ha remain. ${ }^{1}$

In this article, we focus on Indonesia's threatened Middle Mahakam Lakes. In 2008, the Global Nature Fund (GNF), an international foundation for the protection of environment and nature, tried to draw attention to the dramatic situation of various wetlands in Indonesia by proclaiming the lakes of the Middle Mahakam Wetland as the 'Threatened Lakes of the year 2008' (GNF 2015). The Mahakam Wetland is situated in the province of East Kalimantan and is one of Kalimantan's largest wetlands with an area of $8100 \mathrm{sq}$. $\mathrm{km}$. The wetland is traversed by the Mahakam River, and forms an important water catchment and control system for the natural regulation of the river. It is of great ecological value due to its unique features such as shallow lakes, freshwater swamps and mangrove forests, and the existence of rare and endangered species of birds, monkeys, reptiles and the endangered freshwater Irrawaddy dolphin (Sumaryono 2005). It contains up to 500 million tonnes of peat carbon (Chokkalingam et al. 2007). It is

\footnotetext{
${ }^{1}$ According to the Indonesia's Wetlands Strategy and Action Plan (KLH 2004).
} 
a major breeding ground for freshwater fish ${ }^{2}$ that gives the area a high economic value for the fishing industry.

Since the early 1980s, the Mahakam wetland ecosystem has been increasingly threatened by a variety of factors all of which are related to human activities, such as deforestation, forest fires, mining, monocrop cultivation and pollution (WWF 2005). Deforestation in the watersheds of inflowing rivers is a major threat to the Middle Mahakam Lakes. In 2003, it was estimated that $66 \%$ of the East Kalimantan rainforest had disappeared during the previous 25 years, of which $50 \%$ had been cut in the past decade (WWF 2005). Even restricted and protected forest areas are not safe from logging (Casson and Obidzinski 2002). Coupled with a weakening capacity to absorb rainwater upstream of the Mahakam River, large-scale deforestation might cause higher levels of sedimentation in the wetland lakes. Erosion of the soil in the former forests is expected to decline after a few years when soils stabilise or become covered in new vegetation. Increasing sedimentation from the Mahakam River is however expected to continue and might even increase as logging and natural resource exploitation continues on a large scale in its mountainous watershed area.

Kalimantan was seriously affected by extensive land and forest fires during 1997 and 1998. The fires started in August 1997 and lasted until the end of April 1998. According to Hope et al. (2005) and Chokkalingam et al. (2005), 72-85 \% of the swamp forest was affected by these fires. Large-scale fires can have a detrimental effect on water quality (Gumiri 2000; Earl and Blinn 2003). According to Anderson and Bowen (2000), Page et al. (2002) and Suyanto et al. (2004), the major driving forces behind the fires are plantation developments, by the government and companies, and large-scale transmigration. However, other researchers (Jepson et al. 1998; Dennis et al. 2000; Chokkalingam et al. 2005) have found increasing evidence that local community use of fire for agriculture and fishing (such as burning weeds to clear sailing routes) could also be an important factor.

Increasing agricultural activities are another important threat to water quality in the Middle Mahakam wetlands. Their high fruit production has seen a rapid growth in oil palm plantations on reclaimed peat soil (Phillips 1998, p. 665). This intensive form of agriculture depends heavily on agrochemicals (fertilizers and pesticides) which are a major source of eutrophication and pollution (Gopal 2005, p. 72). With runoff, subsurface flows and periodic floods, the agrochemicals wash off into the rivers and brooks feeding the lake area; influencing sedimentation, vegetation, fish stocks and people's health. The application of agricultural fertilizers also accelerates peat subsidence (Phillips 1998, p. 665). ${ }^{3}$

\footnotetext{
${ }^{2}$ According to Dudgeon (2000a, b), there are 147 species of freshwater fish in the Mahakam River.

3 'The addition of lime and mineral subsoils to peat can increase crop production but it also increases the rate of decomposition'(Farrel and McDonell 1986 in Phillips 1998).
}

Finally, coal mining also poses a significant threat of pollution (Phillips 1998). The mining industry's waste (most prominently acid debris and coal residues from open pit mining) is being washed off into the rivers, lakes and swamps during heavy rainfalls or flooding causing increases in several sulphur chemical combinations in the water (UNEP 2006).

Against this backdrop, people living in the Middle Mahakam Wetlands area have noticed various changes in their local environment, especially with regard to water quality since this affects their ability to make a living. ${ }^{4}$ Water quality (chemical and physical) is a key climate-sensitive factor in determining the amount and quality of fish habitat in a wetland (Mortsch 1998). So, apart from any threats to the health of humans, any changes in the water quality of the lakes may lead to serious reproduction problems for the fish.

In this article, we verify local people's perceptions, with the support of water quality measurements taken in 1998 and 2006. By comparing the samples from two dates we also want to report data that can be used to determine future trends. We include water quality measurements from 1992 to 93 and 1995 to further evaluate the changes in water quality over time. There are no previous studies of water quality trends in the Middle Mahakam Lakes, nor in other wetlands of Kalimantan. We evaluated the water quality of the Middle Mahakam Lakes, by comparing the 2006 measurements with data reported for similar water systems in Kalimantan and with water quality standards established by the USA, the World Bank, Australia, Malaysia and South Africa.

\section{Site Information/Study Area}

The Middle Mahakam wetlands are located in East Kalimantan, covering an area of $18.000 \mathrm{~km} 2$ between $180 \mathrm{~km}$ and $375 \mathrm{~km}$ upstream of the mouth of the Mahakam River (Fig. 1). The area is traversed by the river's silty clay levee systems (1-4 km wide) and forms an important water catchment area and control system for the natural regulation of the river. The Middle Mahakam wetlands constitute the largest freshwater system of East Kalimantan and some of the most productive freshwater fisheries in Southeast Asia (MacKinnon et al. 1996, p. 460). It includes $5.000 \mathrm{~km}^{2}$ seasonally inundated swampforest underlain by thick layers of peat and contains $500 \mathrm{~km}^{2}$ permanent swamplands and roughly 32 minor lakes (between 0.1 and $20 \mathrm{~km}^{2}$ in area) and three major lakes: Jempang $\left(150 \mathrm{~km}^{2}\right)$, Semayang $\left(130 \mathrm{~km}^{2}\right)$ and Melintang $\left(110 \mathrm{~km}^{2}\right)$. Many of these lakes are 'oxbow lakes', formed

\footnotetext{
${ }^{4}$ See Nooteboom and De Jong (2010) for an elaboration of the implications of this perspective for the local population.
} 


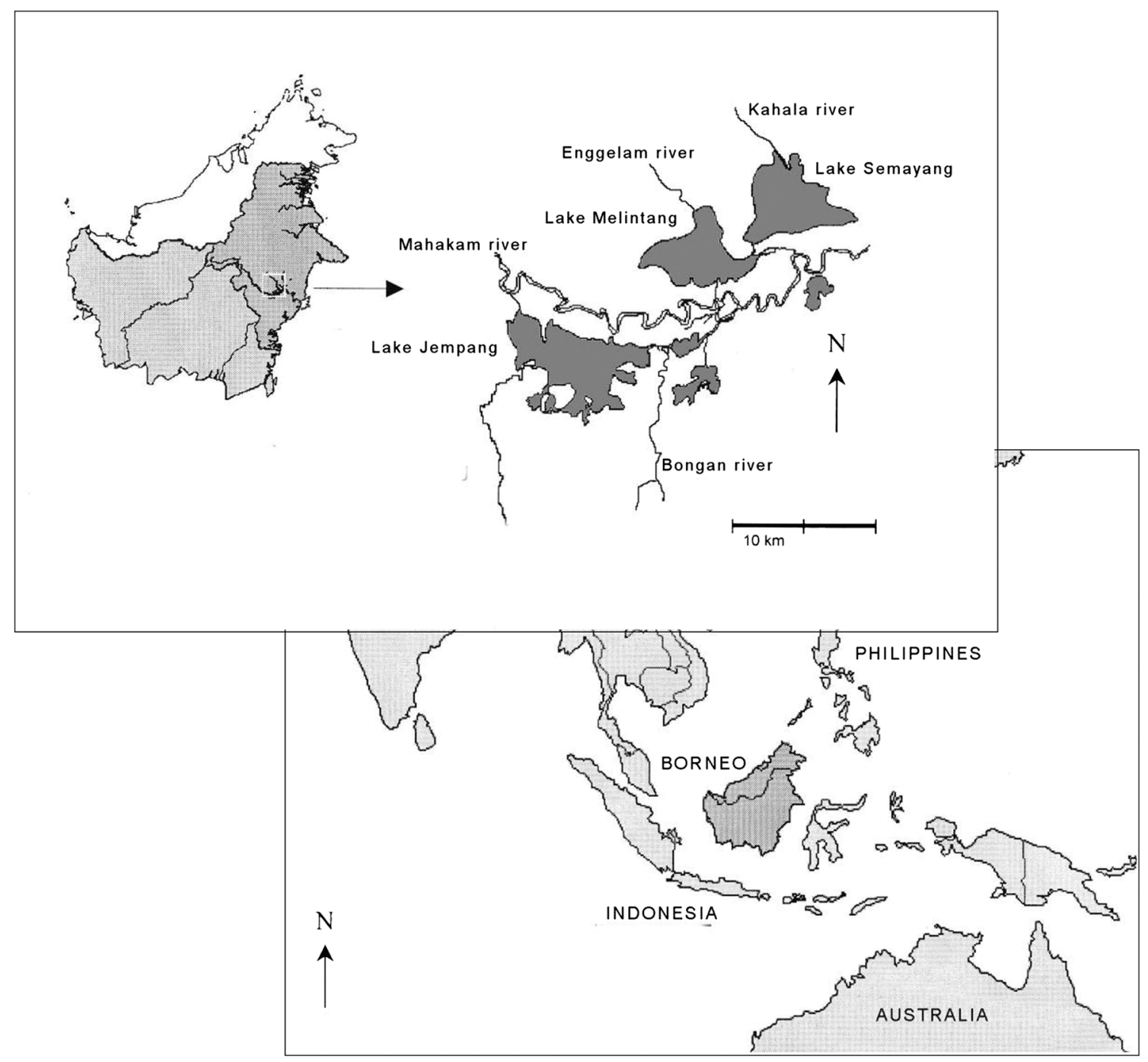

Fig. 1 Map showing the Middle Mahakam lakes and rivers in the province of East Kalimantan, Indonesia

out of old bends in the river that have been cut off from the Mahakam River (MacKinnon et al. 1996, p. 460). This study was limited to the three major lakes, further referred to as the Middle Mahakam Lakes (MML).

The lakes have inward and outward water flows to the Mahakam River and as such function as aquifers by storing water during wet periods and releasing this water slowly when rainfall is low. As such, they help to reduce flood peaks and provide water in dry periods (Andriesse 1988). A few sizeable freshwater tributaries flow into the lakes (most notably River Enggelam into Lake Melintang, the Bongan and Ohong rivers into Lake Jempang and River Kahala into Lake Semayang).

Rainfall averages 1900-2000 mm per year, of which most falls between the end of December and April (Weidemann 2002) with the least in August. With the changing water levels, the total water surface area of the three lakes peaks at around $600 \mathrm{~km}^{2}$ but falls to almost zero in the dry season (Sumaryono 2005). Measurements in July 2006 indicated that Lake Melintang was the shallowest of the three main lakes with an average depth of $2.0 \mathrm{~m}( \pm 1.0 \mathrm{~m})$ compared to $2.2 \mathrm{~m}$ $( \pm 0.79 \mathrm{~m})$ in Lake Jempang and $2.3 \mathrm{~m}( \pm 0.86 \mathrm{~m})$ in Lake Semayang. Locals recall water levels as high as three metres for over a month dropping to almost zero during the dry season. However, during recent years, flood levels have increased and water level fluctuations in the three major wetland lakes have reached over six metres, causing flooding not seen before.

The water that drains from the peat swamps is acidic, low in inorganic ions and oxygen, and has high concentrations of humid acid that gives it a characteristic 'blackwater' appearance (Bennett and Gombek 1992). While the soil in the area is dominated by red-yellow podsolic (clay), the soil near the lakes is peaty 
(organosol soil type), and is low in nutrients (CV. Portal Konsultan 2006). As it is formed from decomposed swamp plant remnants it has a high acidity. ${ }^{5}$

The region is characterised by having wet and dry seasons with a relatively constant temperature throughout the year $\left(25-30{ }^{\circ} \mathrm{C}\right)$. The shallow still waters of the swamps and lakes can become very hot in dry weather and the water conditions provide an environment that is physiologically more taxing than that found in fastflowing or deeper waters: 'the hotter the water, the less oxygen it can hold' (MacKinnon, et al. 1996, p. 155). This scenario is not uncommon for tropical aquatic systems, and fish in these swampy areas have developed novel ways to absorb oxygen in order to survive.

The lakes are very productive freshwater fisheries with many black fish (catfish, channids, anabantids), while the blackwater rivers that drain the swamps and enter the lakes yield especially white fish (cyprinids). There are nine villages located on the edges of the three large lakes or at the mouth of the rivers that flow into the lakes, with a total population of 14,600 people in 2005. The primary livelihood source of these 'wetlander communities' is fishing. It is estimated that in 2007 at least 12,000 tonnes of fish were caught and 8200 tonnes of fish were harvested from floating breeding cages (aquaculture) (Department of Fisheries and Livestock 2008). The quantities of fish produced are important for the regional economy.

The natural vegetation around the lakes is a mosaic of specialised closed forests that reflect the hydrology, nutritional status and disturbance history of the region (Hope et al. 2005). However, the United Nations Environment Programme (UNEP) estimated that, by 2006, over 100,000 ha had been given over to agriculture, coal-mining and oil palm plantations (UNEP 2006). Four logging companies with concession areas are situated in the northern part of the lakes. Other concessions in the lake area have been granted to three industrial forest companies (rubber), and four oil-palm plantation companies, mainly situated in the vicinity of Jempang Lake. One coalmining company is located south of Lake Jempang, along the Ohong River that flows into that lake.

\footnotetext{
5 According to Budiono (2009), the $\mathrm{pH}$ of the soil around Lake Jempang is 3 5.6, while CV Portal Konsultan (2006) measured a pH of 4.2-4.8 in the wider lake region. Phillips (1998) argues in his study on Borneo's (including Kalimantan) peat lands that the water draining from a peatswamp is acidic $(\mathrm{pH} 3-4$, $5)$.
}

\section{Methods and Analysis}

\section{Methods}

Water quality measurements were taken in the three Middle Mahakam Lakes during early July 2006 (between the wet and the dry seasons). To allow for a representative sampling across the lakes, various sampling locations were identified by GPS coordinates. Both the time of the year and the sampling locations were similar to those used with the water quality measurements taken in 1998 (end of June), and similar techniques were used to enhance the comparability of the results. ${ }^{6}$ The waterquality measurements of 1998 were commissioned by the Institute of Indonesian Science in cooperation with the Environmental Research Centre of Mulawarman University and presented in a unpublished report (see Mursidi 1998).

In 2006, 38 locations (see Fig. 2) were sampled in both the lakes and the connecting rivers in the direction against the water flow: starting in Lake Semayang, followed by Lake Melintang and finally Lake Jempang. A GPS device was used to determine the coordinates of each sampling location. In-situ measurements were made of the $\mathrm{pH}$ value, the electrical conductivity (EC) and the temperature of the water. ${ }^{7}$ Half-litre water samples were collected in bottles for transport to the Water Quality Laboratory at Mulawarman University in Samarinda, where they were stored at $4{ }^{\circ} \mathrm{C}$. Samples used to test for dissolved oxygen (DO) were kept according to the Winkler Titration method procedure (Winkler 1888; Culberson 1991). In the laboratory, turbid samples were filtered through Whatman general purpose filter paper to reduce turbidity. Sampling and analyses of carbon dioxide $\left(\mathrm{CO}_{2}\right)$, alkalinity, hydrogen sulphide $\left(\mathrm{H}_{2} \mathrm{~S}\right)$, ammonia $\left(\mathrm{NH}_{3}-\mathrm{N}\right)$, nitrates $\left(\mathrm{NO}_{3}-\mathrm{N}\right)$, phosphates $\left(\mathrm{PO}_{4}\right.$-ortho), biological oxygen demand $\left(\mathrm{BOD}_{5}\right)$, chemical oxygen demand (COD), total suspended solids (TSS) and total dissolved solids (TDS) were carried out according to Indonesia's National Standards for water quality measurements. ${ }^{8}$

\footnotetext{
${ }^{6}$ Ir. Mursidi from the Research Centre for Environmental Studies at the University of Mulawarman, Samarinda, Indonesia led the teams that measured the water quality both in 1998 and 2006.

${ }^{7}$ The $\mathrm{pH}, \mathrm{EC}$ and temperature values were measured according to Indonesia's National Standards for water quality measurements, SNI 19-1140-1991, SNI06-2413-1991 and SNI 06-6989.23-2005, respectively.

${ }^{8} \mathrm{H}_{2} \mathrm{~S}$ (SNI 06-6875-2002), $\mathrm{NH}_{3}-\mathrm{N}$ (SNI 06-2479-1991), $\mathrm{NO}_{3}-\mathrm{N}$ (SNI 036856-2002), PO4-ortho (SNISNI 03-4151-1996), BOD (SNI 06-24241991), COD (SNI 06-2434-1991), TSS (SNI 06-2413-1991 - 3.6) and TDS (SNI 06-2413-1991 - 3.7).
} 


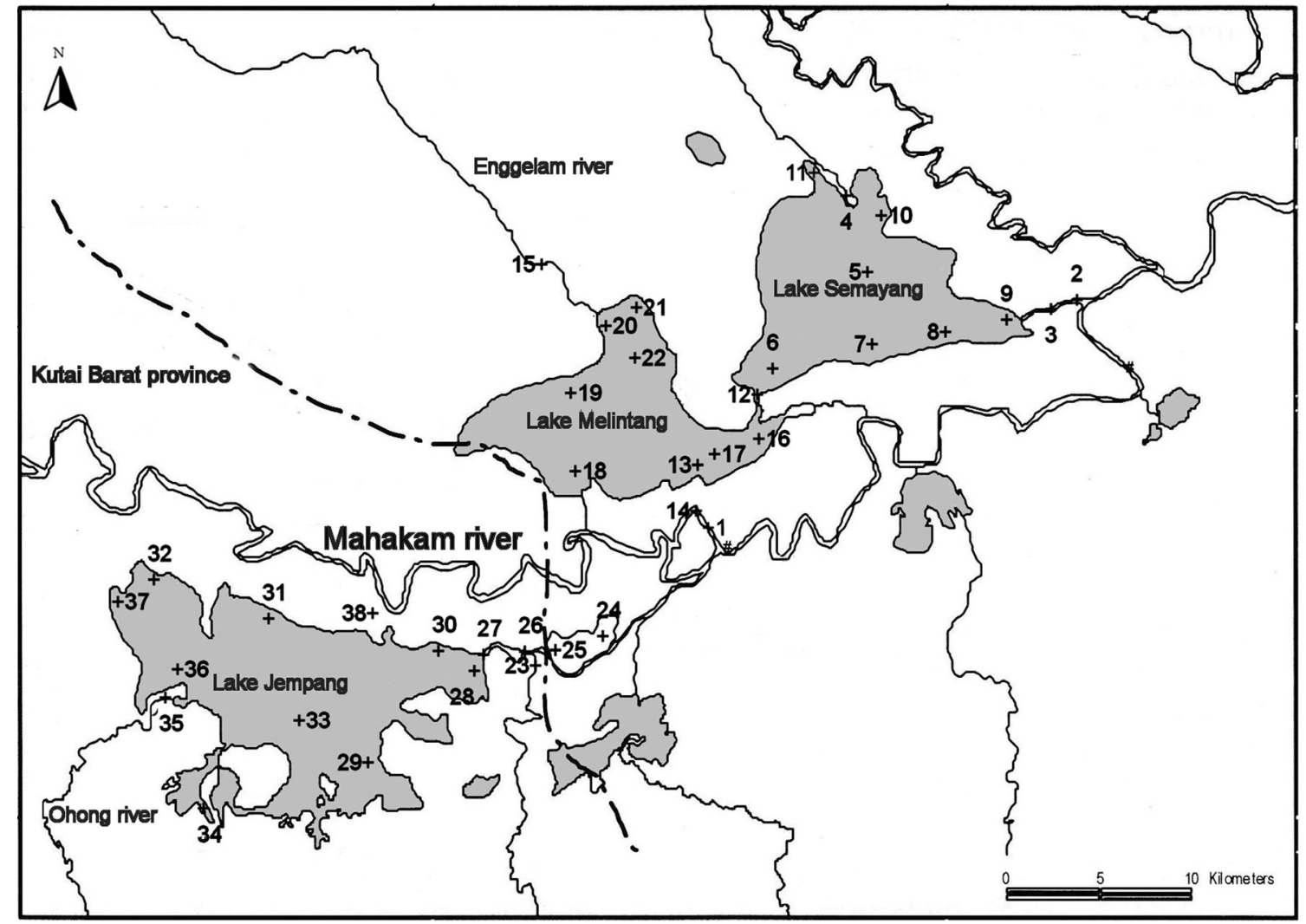

Fig. 2 Map of the MML showing the 38 sampling sites of the 2006 water quality measurements

\section{Statistical Analyses}

A simple one-way ANOVA was performed to test for differences in the means between the three lakes. Although ANOVA is seen as a robust test, it strictly requires equal sample sizes, normally distributed data and equal variances. In our case, the samples sizes differ between the two periods (10, 13 and 14 for Lakes Semayang, Melintang and Jempang respectively in 1998, and 7, 7 and 9 in 2006), ${ }^{9}$ although these differences are relatively small. The data were tested for normality using the Kolmogorov-Smirnov and the Shapiro-Wilk tests, and for equal variances using Levene's test. To explore the impact of violations of the assumptions underlying a simple one-way ANOVA, two alternative versions of the F-ratio were calculated (Brown-Forsythe F and Welch's F). Three different post-hoc tests (Bonferroni, Gabriel and Games-

\footnotetext{
${ }^{9}$ For the sampling locations in 2006 see Fig. 2. The marked locations 5-11 were included in the sample of Lake Semayang, 16-22 in the sample of Lake Melintang and 28-34, 36, 37 in the sample of Lake Jempang. These sampling locations are matching more or less with the measurements taken in 1998. However, next to these locations, some more waterquality measurements were taken in 1998 for Lake Semayang (three), Melintang (six) and Jempang (five).
}

Howell) were performed to identify relevant differences between the lakes. Finally, an exploratory principal component analysis (PCA) with orthogonal rotation (varimax) was conducted on 10 water quality parameters present in the 2006 dataset: transparency, $\mathrm{pH}, \mathrm{DO}, \mathrm{CO}_{2}$, alkalinity, TSS, TDS, turbidity, COD and nitrates. Other parameters were excluded because the KMO statistic indicated diffusion to be present in the pattern of correlations (i.e., $\mathrm{KMO}<0.5$ ).

If no significant differences were found between the lakes with either the simple one-way ANOVA, or in BrownForsythe F or Welch's F ratios, the data from each individual lake, measured in the same year, were pooled and a $t$-test was performed to identify differences between 1998 and 2006. If the tests pointed towards a difference between the three lakes in either 1998 or 2006, then each lake was tested separately for differences between 1998 and 2006 using a $t$-test.

\section{Results}

In identifying possible changes in the water quality of the MML, we start by comparing the measurements for the three lakes in 1998 and then in 2006. In 1998, significant 
differences between the three lakes were found in terms of temperature, transparency, total dissolved solids (TDS), conductivity, $\mathrm{pH}$, dissolved oxygen (DO), nitrates and phosphates. In 2006, significant differences between the lakes were found for total suspended solids (TSS), $\mathrm{pH}$ and hydrogen sulphide. Subsequently, only the data for alkalinity and chemical oxygen demand (COD) were pooled across the three lakes. The results of the t-tests are listed in Table 1.

Although water quality measurements in the MML are scarce, measurements in 1992-93 (Suryadiputra et al. 2000) and 1995 (UGM in Persero PT. Virama Karya and Pt. Indra Karya 2001/2002) have been reported. ${ }^{10}$ Further, Ishikawa et al. (2006) reported water quality data for a similar water system in Central Kalimantan and Hartoto (2010) reported water quality data for the Lake Loa Kang Fishery Reserve, part of the Mahakam basin. ${ }^{11}$ The data are listed in Table 2. Most of the 2006 measured values in MML fall within the range of values previously reported, making it difficult to draw unequivocal conclusions about changes in water quality. The 1995 values for nitrates and phosphates must be questioned because they differ by more than a factor of 10 from the other measurements. ${ }^{12}$ The only consistent pattern is that the upper limit of the biological oxygen demand reported in 2006 is consistently higher than that recorded in 199293 and 1995.

There are only three water quality parameters that differed significantly between the three lakes in 2006: total suspended solids, $\mathrm{pH}$ and hydrogen sulphide. Lake Melintang shows relatively low $\mathrm{pH}$ values in the northern part of the lake $(\mathrm{pH}=5.2-5.7$ at sampling points 20 22 ) and relatively high hydrogen sulphide levels throughout the lake $(1.6-2.1 \mathrm{mg} / \mathrm{l})$. This is in line with the low $\mathrm{pH}$ (4.5) and high hydrogen sulphide concentration $(1.1 \mathrm{mg} / \mathrm{l})$ measured in River Enggelam (sampling location 15), its main tributary.

Another option, when trying to evaluate the water quality of the MML, is to compare the 2006 measurements with published water quality standards. Since fishing is the primary livelihood source for the local wetland communities in the MML, water quality criteria for the protection of aquatic ecosystems and aquaculture species were gathered (Table 3). The second column in Table 3 lists recommended national water quality

\footnotetext{
$\overline{10}$ The sampling strategy of both measurements is not further specified.

${ }^{11}$ Ishikawa et al. (2006) conducted water quality measurements during MayJune 2004 at the two rivers Kahayan and Rungan (5 locations) and one at the centre of surrounding oxbow and flooded lakes (10 locations). Hartoto (2010) conducted water quality measurements at 10 locations, and at these locations six sampling sessions were conducted between June 2003 to 28 November 2004.

12 The 1995 data shows that the values for nitrates (ppm) for Lake Semayang is 5.0-7.8, for Lake Melintang is $0.8-5.3$ and for Lake Jempang is 12.7-17.2. The values for phosphates (ppm) are $20-3.3,0.8-1.3$ and $1.7-4.2$, respectively.
}

criteria for the protection of aquatic ecosystems in the USA (US-EPA 2009). The last four columns list water quality standards for the protection of aquaculture as proposed by the Worldbank (Zweig et al. 1999) and as applicable in Australia (ANZECC 2000), Malaysia (Anonymous 2006) and South Africa (DWAF 1996), respectively. Where the 2006 measured averages exceed the recommendation in at least one of the lakes, the figures are highlighted in a bold typeface. Violations were found for $\mathrm{pH}$, dissolved oxygen, alkalinity, hydrogen sulphide and ammonia. Only the Australian ammonia criterion is violated, and their standard is much stricter $(0.03 \mathrm{mg} / \mathrm{l})$ than seen elsewhere. According to the underlying report (AZNECC 2000), this criterion is based on the South African water quality guidelines, but South Africa uses a standard of $0.3 \mathrm{mg} / \mathrm{l}$ for warmwater fish which is a factor of 10 higher than the Australian value raising question marks over the validity of the latter.

To identify significant differences between the three lakes, a principal component analysis was conducted on the 2006 water quality data. The analysis resulted in three PCA axes where some a-typical values exceeded unity (Table 4). Despite the low number of samples, the results were reasonable with a KMO value of 0.69 and multiple factor loadings exceeding 0.6. The first PCA axis is related to the variation in acidity and combines $\mathrm{pH}$, alkalinity and nitrate levels. High nitrate levels coincide with low $\mathrm{pH}$ and alkalinity values, especially in Lake Semayang. The second PCA axis is associated with variations in water clarity and combines transparency, turbidity, total dissolved solids (TDS) and chemical oxygen demand (COD). High levels of dissolved solids coincide with low transparency and high turbidity and COD levels. The variation is largest in Lake Jempang which has high TDS inputs from its main tributaries, i.e., River Bongan (TDS $=114 \mathrm{mg} / \mathrm{l}$ ) and River Ohong $(80 \mathrm{mg} / \mathrm{l})$. The third axis is associated with respiration and combines dissolved oxygen and $\mathrm{CO}_{2}$ levels. High oxygen levels coincide with low $\mathrm{CO}_{2}$ levels. Here, the variations are largest in Lake Jempang and Lake Semayang.

\section{Discussion and Conclusions}

Measurements show that the water quality of the MML improved considerably between 1998 and 2006. The total dissolved solids (TDS), conductivity, nitrates, phosphates and chemical oxygen demand improved in all three lakes, whereas transparency, $\mathrm{pH}$, dissolved oxygen (DO) and hydrogen sulphide levels improved in two of the three lakes. Alkalinity decreased in all three lakes. 


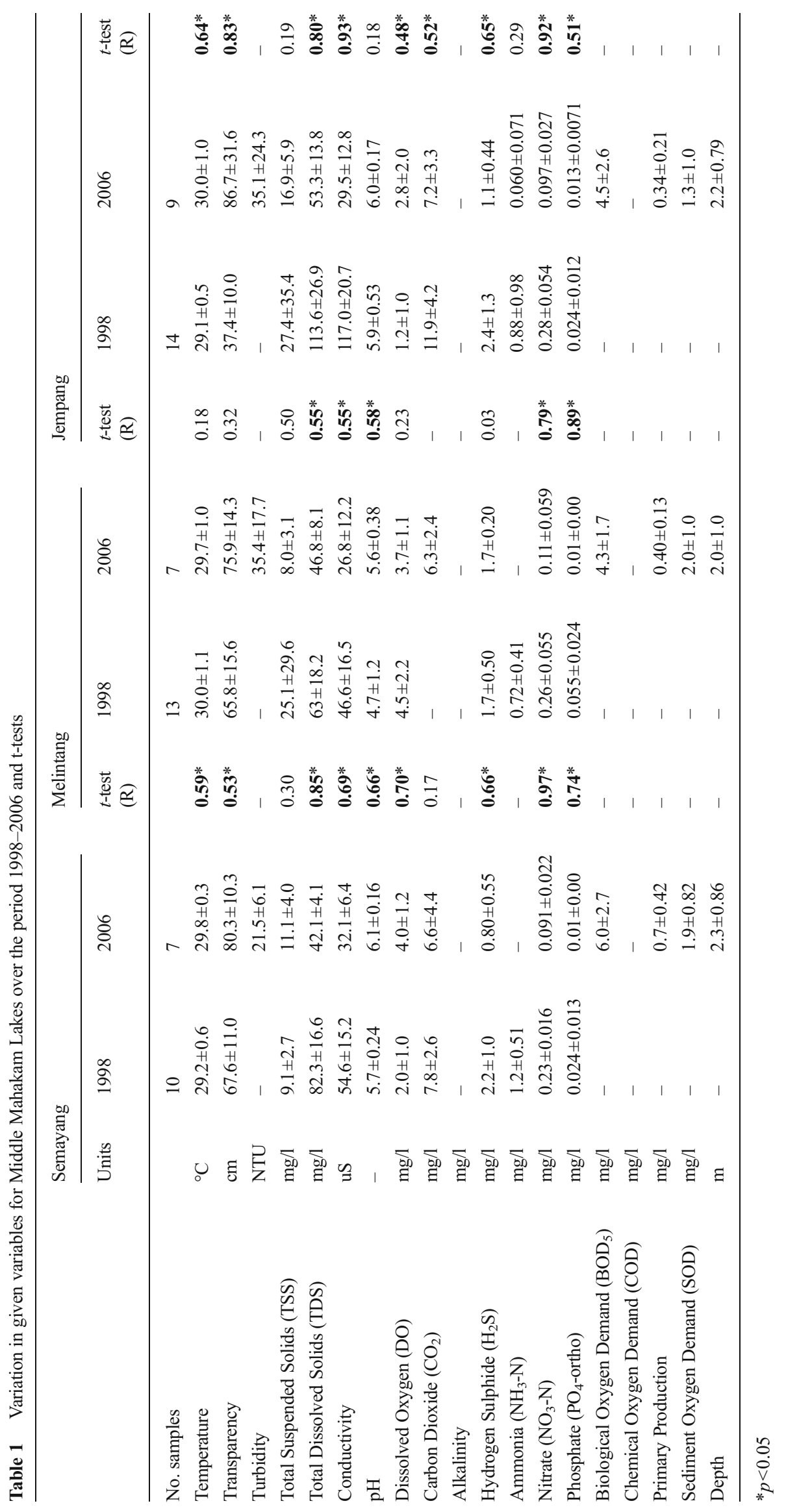


Table 2 Comparison of the 2006 MML water quality data with data from 1992 to 93 and 1995 and with data for comparable water systems in Central Kalimantan (Ishikawa et al. 2006) and the Lake Loa Kang Fishery Reserve (Hartoto 2010)

\begin{tabular}{|c|c|c|c|c|c|c|c|c|c|c|c|}
\hline & \multicolumn{3}{|l|}{ Semayang } & \multicolumn{3}{|l|}{ Melintang } & \multicolumn{3}{|l|}{ Jempang } & \multirow{2}{*}{$\begin{array}{l}\text { C Kal } \\
2004\end{array}$} & \multirow{2}{*}{$\begin{array}{l}\text { LLKFR } \\
\text { 2003-04 }\end{array}$} \\
\hline & $1992-93$ & 1995 & 2006 & $1992-93$ & 1995 & 2006 & $1992-93$ & 1995 & 2006 & & \\
\hline No. samples & - & - & 7 & - & - & 7 & - & - & 9 & 15 & 10 \\
\hline Temperature $\left({ }^{\circ} \mathrm{C}\right)$ & $27-32$ & - & $29.5-30.3$ & $28.5-32$ & - & $27.7-30.8$ & $28-33$ & 34 & $28.5-31$ & $27.8-32.3$ & $26.7-35.8$ \\
\hline Transparency $(\mathrm{cm})$ & - & $25-38$ & $68-100$ & - & $15-25$ & $50-92$ & - & $<5$ & $28-125$ & - & - \\
\hline Turbidity (NTU) & - & - & $12.2-29.8$ & - & - & $13.9-59.9$ & - & - & $8.75-28.75$ & $11.8-181$ & $11-774$ \\
\hline Conductivity $(\mu \mathrm{S} / \mathrm{m})$ & $13-100$ & $15-33$ & $23.1-39.5$ & $10-57$ & $26-44$ & $18.7-39.2$ & - & $43-92$ & $1.6-43.2$ & $13-59$ & $19-143$ \\
\hline $\mathrm{pH}$ & $5.0-7.5$ & $4.5-5.5$ & $5.8-6.3$ & $5.2-7.3$ & $4.5-5.5$ & $5.1-6.1$ & $5.6-6.3$ & $4.5-5.5$ & $5.8-6.3$ & $4.2-6.3$ & $4.9-6.9$ \\
\hline $\mathrm{DO}(\mathrm{mg} / \mathrm{l})$ & $1.4-9.3$ & $1.3-5.0$ & $2.3-5.3$ & $1.8-9.1$ & $2.4-5.2$ & $2.9-5.6$ & - & $3.8-6.5$ & $0.2-5.2$ & $3.0-5.2$ & $0.2-9.7$ \\
\hline Alkalinity (mg/l) & $3.9-29.4$ & - & $10.1-14.7$ & $6.3-27.3$ & - & $5.5-16.8$ & $6.3-23.1$ & - & $6.3-13.4$ & - & - \\
\hline $\mathrm{NO}_{3}-\mathrm{N}(\mathrm{mg} / \mathrm{l})$ & 0.001 & $0.8-5.3$ & $0.07-0.13$ & - & $5.0-7.8$ & $0.06-0.22$ & - & $12.7-17.2$ & $0.07-0.13$ & - & $0.02-0.57$ \\
\hline $\mathrm{PO}_{4}$-ortho $(\mathrm{mg} / \mathrm{l})$ & - & $0.8-1.3$ & 0.01 & - & $2.0-3.3$ & 0.01 & - & $1.7-4.2$ & $0.01-0.03$ & - & - \\
\hline $\mathrm{BOD}_{5}(\mathrm{mg} / \mathrm{l})$ & $0.7-6.6$ & $0.9-1.9$ & $3.0-10.3$ & $1.3-5.1$ & $2.4-5.2$ & $3.3-7.0$ & - & $1.1-2.7$ & $1.3-9.2$ & - & - \\
\hline
\end{tabular}

The measured improvement in water quality over the period 1998-2006 came as a surprise. Based on the interviews with local people and the increase in human activities in the area, we had expected the water quality to have deteriorated. This prompted the question as to whether there were confounding factors in the measurements of 1998 or 2006.

The relatively poor water quality in 1998 can be attributed to the extensive land and forest fires that raged in this area in 1997-98. The fires possibly resulted in an increased input of elements and organic substances into the MML, explaining the low $\mathrm{pH}$ values, the high levels of nutrients and dissolved solids, and the high COD and low oxygen levels. The pH of rainwater in Palanka Raya (Central Kalimantan), dropped to 4.61 in 1997, whereas the regional average was 5.88 in 1993 (Gumiri 2000), maybe leading to the low $\mathrm{pH}$ values in Lakes Semayang and Melintang. Forest fires also result in an increase in nutrient availability entering the water system through run-off and deposition. Earl and Blinn (2003) reported an increase in nitrates, phosphates and alkalinity after ash from forest fires entered USA streams, again consistent with our results for all three lakes. The increased input of nutrients and ash particles is likely to explain the high levels of chemical oxygen demand and total dissolved solids in 1998 (both indicators for eutrophication) and the low levels of dissolved oxygen and transparency. However, the level of total suspended solids in 1998 is similar to that in 2006, whereas one would expect a higher level in 1998 after the ash input from fires. Caldwell et al. (2000) offer a possible explanation in that they noticed that the level of total suspended solids after a fire only increases in waters bordering the fires, and decreases rapidly once the fires are extinguished. Another plausible explanation is that the input of total suspended solids due to human activities (e.g., mining and palm oil plantations) increased over the 1998-2006 period.
The improvement in water quality between 1998 and 2006 is most marked in Lakes Semayang and Jempang with a smaller improvement in Lake Melintang. Parameters such as dissolved oxygen, hydrogen sulphide and transparency do not show significant improvements in that period in Lake Melintang, maybe indicating that Lake Melintang was less affected by the 1998 fires. This could be explained by its position between the two other lakes resulting in a relatively small drainage basin and a larger retention time. Based on these findings, it seems safe to conclude that the 1998 measurements were not representative of 'normal' conditions and were heavily impacted by the 1997-98 fires that raged in Kalimantan.

In considering discarding the 1998 data as being unrepresentative, we have evaluated the water quality of the MML, and especially changes over time, by comparing our measurements with earlier data previously reported in 1992-93 and 1995. The analysis shows that the only consistent pattern is that the upper limit of the biological oxygen demand reported in 2006 is consistently higher than that recorded at the earlier dates, which suggests an increase in organic material in the lakes. This is in line with observations by local fishermen. Mursidi (pers com), also measured changing nutrient content in the water of the three MMLs and noted high levels for much longer periods than previously. The growing volumes of weeds are the result of both increased sedimentation as well as the rising nutrient content. The rapid increase of aquatic plants in the large lakes (mainly Salvinia sp. and Eichhornia crassipes, Mimosa pigra and Polygonum barbatum) (Gonner 2000) may not only affect the water quality through the decomposition of the dead vegetation but also has consequences for the habitat of white-fish species, and eventually the more resilient black-fish species, by reducing the depth and the water flows of the lakes. 
Table 3 Water quality criteria for the protection of aquatic ecosystems (USA) and aquaculture (World Bank, Australia, Malaysia and South Africa)

\begin{tabular}{|c|c|c|c|c|c|}
\hline Parameter & $\mathrm{USA}^{1}$ & World Bank ${ }^{2}$ & Australia $^{3}$ & Malaysia $^{4}$ & South Africa ${ }^{5}$ \\
\hline Temperature & $\pm 1{ }^{\circ} \mathrm{C}$ & $29-30^{\circ} \mathrm{C}^{6}$ & $\pm 2{ }^{\circ} \mathrm{C}$ & $\pm 2{ }^{\circ} \mathrm{C}$ & $28-30{ }^{\circ} \mathrm{C}^{7}$ \\
\hline Transparency & $\mathrm{NA}^{8}$ & NA & NA & NA & NA \\
\hline Turbidity & $\mathrm{NA}^{8}$ & NA & NA & NA & NA \\
\hline Total Suspended Solids (TSS) & $\mathrm{NA}^{8}$ & $<25-80 \mathrm{mg} / \mathrm{l}$ & $<40 \mathrm{mg} / \mathrm{l}$ & $<150 \mathrm{mg} / 1$ & NA \\
\hline Total Dissolved Solids (TDS) & $<250 \mathrm{mg} / 1$ & NA & $<3000 \mathrm{mg} / 1$ & NA & $<20000 \mathrm{mg} / \mathrm{l}$ \\
\hline Conductivity & NA & NA & NA & NA & NA \\
\hline $\mathrm{pH}$ & $6.5-9.0$ & $6.5-9.0$ & $5.0-9.0$ & $5.0-9.0$ & $6.5-9.0$ \\
\hline Dissolved Oxygen (DO) & $>5.5^{9}$ & $>3.0 \mathrm{mg} / 1$ & $>5.0 \mathrm{mg} / 1$ & $3-5 \mathrm{mg} / \mathrm{l}$ & $5-8 \mathrm{mg} / 1$ \\
\hline Carbon Dioxide $\left(\mathrm{CO}_{2}\right)$ & NA & $<15 \mathrm{mg} / \mathrm{l}$ & $<10 \mathrm{mg} / \mathrm{l}$ & NA & $<12 \mathrm{mg} / \mathrm{l}$ \\
\hline Alkalinity & $>20 \mathrm{mg} / \mathrm{l}$ & $20-400 \mathrm{mg} / 1$ & $>20 \mathrm{mg} / \mathrm{l}$ & NA & $20-400 \mathrm{mg} / \mathrm{l}$ \\
\hline Hydrogen Sulphide $\left(\mathrm{H}_{2} \mathrm{~S}\right)$ & $<2 \mu \mathrm{g} / 1^{10}$ & NA & $<1 \mu \mathrm{g} / 1$ & NA & $<1 \mu \mathrm{g} / 1$ \\
\hline Ammonia $\left(\mathrm{NH}_{3}-\mathrm{N}\right)$ & $<1.03^{11}$ & $<1.0 \mathrm{mg} / 1$ & $<30 \mu \mathrm{g} / \mathrm{1}^{7,12}$ & $<0.9 \mathrm{mg} / \mathrm{l}$ & $<0.3 \mathrm{mg} / \mathrm{l}^{7}$ \\
\hline Nitrate $\left(\mathrm{NO}_{3}-\mathrm{N}\right)$ & $<10 \mathrm{mg} / \mathrm{l}^{13}$ & $<3.0 \mathrm{mg} / 1$ & $<50 \mathrm{mg} / \mathrm{l}$ & NA & $<300 \mathrm{mg} / 1$ \\
\hline Phosphate $\left(\mathrm{PO}_{4}\right.$-ortho) & NA & NA & $<100 \mu \mathrm{g} / 1$ & $<100 \mu \mathrm{g} / 1$ & $<100 \mu \mathrm{g} / 1$ \\
\hline Biological Oxygen Demand $\left(\mathrm{BOD}_{5}\right)$ & NA & $<8-15 \mathrm{mg} / \mathrm{l}$ & $<15 \mathrm{mg} / \mathrm{l}$ & $<6 \mathrm{mg} / 1$ & NA \\
\hline Chemical Oxygen Demand (COD) & NA & NA & $<40 \mathrm{mg} / \mathrm{l}$ & $<50 \mathrm{mg} / \mathrm{l}$ & NA \\
\hline
\end{tabular}

Criteria are highlighted in bold where the average 2006 measured value exceeds this criterion in at least one of the lakes

$N A$ not available

${ }^{1}$ US-EPA 2009 (criteria for the protection of aquatic ecosystems)

${ }^{2}$ Zweig et al. 1999 (if multiple values were reported, those applicable to tropical conditions were chosen)

${ }^{3}$ ANZECC 2000 (guidelines for the protection of aquaculture species)

${ }^{4}$ Anonymous 2006 (Class III: Common, of economic value, and tolerant species; livestock drinking)

${ }^{5}$ DWAF 1996

${ }^{6}$ optimal growth in tropical waters

${ }^{7}$ warm-water species

${ }^{8}$ Settleable and suspended solids should not reduce the depth of the compensation point for photosynthetic activity by more than $10 \%$ from the seasonally established norm for aquatic life

${ }^{9}$ warm water criterion

${ }^{10}$ undissociated $\mathrm{H}_{2} \mathrm{~S}$

${ }^{11}$ at $\mathrm{pH} 6.5$ and $30^{\circ} \mathrm{C}$

${ }^{12}$ cites DWAF 1996 as source but DWAF reports value of $<300 \mu \mathrm{g} / 1$

${ }^{13}$ for domestic water supply

Table 4 Principal component analysis of 2006 water quality data

\begin{tabular}{lcrr}
\hline & \multicolumn{2}{l}{ PCA Axis } & \\
\cline { 2 - 3 } & 1 & 2 & 3 \\
\hline $\mathrm{pH}$ & 0.926 & \\
$\mathrm{Nitrate}\left(\mathrm{NO}_{3}\right)$ & -0.864 & & \\
Alkalinity & 0.842 & & \\
Total dissolved solids (TDS) & & -0.819 & \\
Transparency & & 0.768 & -0.913 \\
Turbidity & -0.520 & 0.671 & 0.805 \\
Chemical oxygen demand (COD) & -0.406 & & 0.621 \\
Dissolved oxygen (DO) & & & 0.775 \\
CO 2 & & 0.501 & \\
Total suspended solids (TSS) & & 0.832 & \\
Cronbach's alpha (based on standardized items) & 0.884 & & \\
\hline
\end{tabular}


The water quality parameters total suspended solids, $\mathrm{pH}$ and hydrogen sulphide differ significantly between the three lakes in 2006. Possible explanations include drainage from waterlogged peat areas and mining activities. The subsoil of the Eastern Kalimantan peat lands contains high pyrite levels (Diemont et al. 1993), which can result in the release of sulphuric acid if the peat is drained or excavated (Anda et al. 2009). Once released, a lack of oxygen in the water may result in the reduction of the sulphates into sulphides.

Extremely low $\mathrm{pH}$ values may be toxic for fish, either directly or indirectly through the mobilisation of toxic metals and the release of hydrogen sulphide. However, high $\mathrm{pH}$ values may also have detrimental effects. Organic material more easily decomposes under alkaline conditions resulting in falling oxygen levels and an increase in dissolved sulphide levels. Such effects may not only be triggered by an increase in $\mathrm{pH}$ but also by increased inputs of nutrients (such as from fertilizers), organic material (from sanitation) or sediment (from deforestation and erosion). The measurements indicate that this type of effect may already be occurring in the eastern part of Lake Jempang (sampling location 32, 36, 37) where there is a high input of sediment and dissolved solids, and oxygen levels are low. There is a higher concentration of total suspended solids in Lake Jempang than in Lake Melintang. This can be explained by the relatively high sediment input from River Bongan (TSS $=86 \mathrm{mg} / \mathrm{l})$, one of the Lake Jempang tributaries. These high values could be a reflection of deforestation activities related to the construction of palm plantations. Erosion also influences the chemical content of the water. Erosion of the reddish Kalimantan soil is likely to change the acidity of the water. 'These changes lead to the modification of the habitats through siltation, nutrient enrichment, and consequent biological changes'(Gopal 2005, p. 71).

The principal component analysis indicates that high nitrate levels coincide with low $\mathrm{pH}$ and alkalinity values, especially in Lake Semayang. This could be caused by a reduced growth of vegetation at the low $\mathrm{pH}$ levels, resulting in a reduced uptake of nitrates. Lake Jempang shows the largest variation in the high levels of dissolved solids that coincide with low transparency and high turbidity and COD levels. This is related to the high TDS levels which could be the result of fertilizer use in the oil palm plantations along its main tributaries, i.e., River Bongan and river Ohong.

The water quality standards in Table 3 confirm that fish production in the MML could be impaired by the low levels of $\mathrm{pH}$, dissolved oxygen and alkalinity, and the high levels of hydrogen sulphide. According to Lawson (1995), pH levels between 4.0 and 6.5 , and dissolved oxygen levels between 1.0 and $5.0 \mathrm{mg} / \mathrm{l}$ — as found in many locations in the MML — can result in reduced growth of warm water pond fish. Especially along the southeastern edges of Lake Jempang (sampling location 36), extremely low values of dissolved oxygen (0.2$1.1 \mathrm{mg} / \mathrm{l})$ were measured, which could be lethal for fish.
Although the low alkalinity levels do not have direct adverse effects on fish, they make the system more vulnerable to $\mathrm{pH}$ changes. The most problematic parameter in terms of fish production seems to be hydrogen sulphide. Even levels as low as $0.05 \mathrm{mg} / \mathrm{l}$ are reported to kill fish (Lawson 1995), whereas the levels in MML range from 0.2 to $2.1 \mathrm{mg} / \mathrm{l}$.

However, it should not be overlooked that most water quality standards have been derived for aquatic ecosystems typical of temperate conditions. The low $\mathrm{pH}$, dissolved oxygen and alkalinity levels found, and the high level of hydrogen sulphide, are characteristic of tropical peat wetlands. It is therefore likely that local fish species have adapted to these conditions which makes it dangerous to draw conclusions based on a comparison with water quality standards for temperate regions (Klepper et al. 1992).

Any assessment of the 2006 water quality is further hampered by the lack of reference data on tropical peat land lakes. Tropical peat wetlands are generally characterised by acid conditions in combination with low oxygen levels, resulting in a reduced decomposition of organic material and low nutrient levels. The MML are further characterised by high levels of hydrogen sulphide that originate from the underlying acidic sulphur soils. There seems to be a delicate balance in the MML between the $\mathrm{pH}$ value and the levels of oxygen, nutrients and hydrogen sulphide, which could easily be disturbed if these lakes and their back lands are inappropriately managed. The low alkalinity values indicate that the system is prone to $\mathrm{pH}$ changes which could be triggered by an increased input of acids, possibly as a consequence of deforestation, mining activities or the drainage of peat lands. An example where this is happening is the discharge of acidic water from River Enggelam into Lake Melintang (sampling locations 20 and 21 ), although it is not clear whether this reflects a natural situation or is the result of human activity.

We conclude that there is an urgent need for reference values for the physical and chemical water quality parameters of tropical peat land lakes and an improved understanding of the geochemical processes that maintain the delicate balance between these parameters. In the face of limited available robust baseline data collections of the world's wetlands, limited (panel) datasets on water quality of tropical wetland lakes, in a great variety of contexts, are useful to obtain a more differentiated understanding of the processes and impacts on these poorly monitored but important wetland systems. Only if we understand these processes can we counterbalance current threats and develop a sustainable management strategy for the Middle Mahakam wetland lakes and similar tropical wetland regions elsewhere in the world.

Acknowledgments The article is based on research funded by NWO/ ALV (Netherlands Organisation for Scientific Research/Earth and Life sciences) and carried out between 2005 and 2009 in cooperation with 
the Research Centre for Environmental Studies (PPLH), Mulawarman University, Samarinda, Indonesia.

Open Access This article is distributed under the terms of the Creative Commons Attribution 4.0 International License (http:// creativecommons.org/licenses/by/4.0/), which permits unrestricted use, distribution, and reproduction in any medium, provided you give appropriate credit to the original author(s) and the source, provide a link to the Creative Commons license, and indicate if changes were made.

\section{References}

Anda M, Siswanto AB, Subandiono RE (2009) Properties of organic and acid sulfate soils and water of a 'reclaimed' tidal backswamp in Central Kalimantan, Indonesia. Geoderma 149:54-65

Anderson IP, Bowen MR (2000) Fire zones and the threat to the wetlands of Sumatra, Indonesia. Report MoFEC-EU Forest Fire Prevention and Control Project, Palembang, Indonesia

Andriesse JP (1988) Permanent constraints in peat reclamation. Nat Manag Trop Peat Soils (FAO Soils Bull) 59:81-91

Anonymous (2006) National water quality standards for Malaysia. http:// www.wepa-db.net/policies/law/malaysia/eq std.htm

ANZECC [Australian and New Zealand Environment and Conservation Council] (2000) Australian and New Zealand guidelines for fresh and marine water quality. Canberra, Australia.http://www.mincos. gov.au/publications/australian_and_new_zealand_guidelines_for_ fresh_and_marine_water_quality

Bennett EL, Gombek F (1992) Wildlife and Conservation in Sarawak's peat swamp forests. In: Aminuddin BY (ed) Tropical Peat, Proceedings of International Symposium on Tropical Peatland, Kuching, Sarawak, Malaysia, 6-10 May 1991. Malaysia Agriculture Research Development Institute \& Department of Agriculture, Kuching (Malaysia)

Budiono (2009) GNF Final report on the community-based reforestation feasibility study of Lake Jempang shores in East Kalimantan, Indonesia. The Conservation foundation for Rare Aquatic Species of Indonesia (RASI), Samarinda (Indonesia)

Caldwell CA, Canavan CM, Bloom NS (2000) Potential effects of forest fire and storm flow on total mercury and methylmercury in sediments of an arid-lands reservoir. Sci Total Environ 260:125-133

Casson A, Obidzinski K (2002) From new order to regional autonomy: shifting dynamics of 'illegal' logging in Kalimantan, Indonesia. World Dev 30(12):2133-2151

Chokkalingam U, Kurniawan I, Ruchiat Y (2005) Fire, livelihoods, and environmental change in the middle Mahakam Peatlands, East Kalimantan. Ecol Soc 10(1):26, http://www.ecologyandsociety.org/ vol10/iss $1 /$ art26/

Chokkalingam U, Suyanto, Permana RP, Kurniawan I, Mannes J, Darmawan A, Khususyiah N, Susanto RH (2007) Community fire use, resource change and livelihood impacts: the downward spiral in the wetlands of southern Sumatra. Mitig Adapt Strat Glob Chang 12(1):75-100

Chokkalingam U, Kurniawan I, Suyanto PRP, Buitenzorgy M, Susanto RH (2009) Fire and land use effects on biodiversity in the southern Sumatran wetland. In: Cochrane MA (ed) Tropical fire ecology; Climate change, land use and ecosystem dynamics. Praxis Publishing Ltd, Chichester, pp 355-385

Culberson CH (1991) Dissolved oxygen. WOCE Hydrographic Programme Operations and Methods (July 1991). Availaible at: http://www.ioos.noaa.gov/qartod/dissolved oxygen/woce o2 recomendations.pdf

CV. Portal Konsultan (2006) Laporan Pendahuluan. Studi Penyusunan Model Pengelolaan Danau Jempang [Introductory Report. Study towards the draft of a model for the Management of Lake Jempang], Samarinda (Indonesia)

Dennis R, Erman A, Meijaard E (2000) Fire in the danau Sentarum landscape. Borneo Res Bull 31:123-137

Department of Fisheries and Livestock [Dinas Perikanan dan Peternakan] (2008) Laporan Tahunan Dinas Perikanan dan Peternakan 2007. Unpublished Report, Dinas Perikanan dan Peternakan, Samarinda

Diemont WH, Pons LJ, Dent DL (1993) Standard profiles of acid sulphate soils. In: Dent DL, van Mensvoort MEF (eds) Selected papers of the Ho Chi Minh City symposium on acid sulphate soils. Publication 53, International Institute for Land Reclamation and Improvement [ILRI], Wageningen

Dudgeon D (2000a) Riverine biodiversity in Asia: a challenge for conservation biology. Hydrobiologia 418:1-13

Dudgeon D (2000b) Riverine wetlands and biodiversity conservation in tropical Asia. In: Gopal B, Junk WJ, Davis JA (eds) Biodiversity in Wetlands: Assessment, functions and conservation, vol 1. Backhuys Publishers, Leiden, pp 35-60

DWAF [Department of Water Affairs and Forestry] (1996) South African Water Quality Guidelines. Volume 6: Agricultural Water Use: Aquaculture 2nd edn. Pretoria, South Africa. Available via: http:// www.dwaf.gov.za/Dir_WQM/docsFrame.htm

Earl SR, Blinn DW (2003) Effects of wildfire ash on water chemistry and biota in South-Western U.S.A. streams. Freshw Biol 48:1015-1030

Giesen W, Sukotjo (1991) Conservation and management of the OganKomering Lebaks South Sumatra, PHPA/AWB Sumatra Wetland Project Report No. 8. Asian Wetlands Bureau, Bogor, Indonesia

GNF [Global Nature Fund] (2015) Threatened Lake of the Year 2008. Available via: http://www.globalnature.org/35773/Living-Lakes/ Threatened-Lake-2015/Threatened-Lake-2008/resindex.aspx

Gonner C (2000) Birds of Lake Jempang and the Middle Mahakam Wetlands, East Kalimantan. Kukila 11:13-36

Gopal B (2005) Does inland aquatic biodiversity have a future in Asian developing countries? Hydrobiologia 542:69-75

Gumiri S (2000) The 1997 land-fire and haze in Central Kalimantan: its possible impact on aquatic ecosystems in the region. Rep Suwa Hydrobiol Station 12:89-96

Hartoto DI (2010) Chronotone and abiotic ecological connectivity in Lake Loa Kang floodplain, East Kalimantan. Oseanol Limnol Indonesia 36:401-421

Hooijer A, Silvius M, Wösten H, Page S (2006) Peat-CO: Assessment of CO emissions from drained Peatlands in SE Asia, Report Q3943. Delft Hydraulics, Delft

Hope G, Chokkalingam U, Anwar S (2005) The stratigraphy and fire history of the Kutai Peatlands, Kalimantan, Indonesia. Quat Res 64:407-417

Ishikawa T, Trisliana Y, Ardianor GS (2006) Dissolved organic carbon concentration of a natural water body and its relationship to water color in Central Kalimantan, Indonesia. Limnology 7:143-146

Jepson P, Momberg F, van Noord H (1998) Trade in reptiles from the Middle Mahakam Lake Area, East Kalimantan, Indonesia, with evidence of a causal link to the forest fires associated with the 1997/98 El Niño phenomena. Bio-regional Management and Integrated Park Management Project Technical Memorandum 3. World Wildlife Fund Indonesia/ United States Agency for International Development

KLH [Kementerian Lingkungan Hidup, State Ministry of Environment] (2004) Strategy Pengelolaan Lahan Basah Nasional [National Wetlands Management Strategy], Jakarta

Klepper O, Chairuddin GT, Iriansyah, Rijksen HD (1992) Water quality and the distribution of some fishes in an area of acid sulphate soils, Kalimantan, Indonesia. Hydriobiol Bull 25:217-224

Lawson TB (1995) Fundamentals of aquacultural engineering. Chapman and Hall, New York 
MacKinnon K, Hatta G, Halim H, Mangalik A (1996) The Ecology of Kalimantan, vol III, The Ecology of Indonesia Series. Periplus Editions, Jakarta/Singapore/Weesp

Mortsch LD (1998) Assessing the impact of climate change on the great lakes shoreline wetlands. Clim Chang 40:391-416

Mursidi (1998) Analisis Invasi Tumbuhan Air Dan Sedimentasi Serta Tekanan Penduduk Terhadap Habitat Pesut Dan Produksi Perikanan Perairan Mahakam Tengah Di Kalimantan Timur [Analysis of the invasion of aquatic plants and sedimentation as well as population pressure on the habitat of river dolphins and the production of fisheries waters of the Middle Mahakam.in East Kalimantan]. Pusat Penelitian Lingkungan Hidup (PPLH), Universitas Mulawarman/Lembaga Ilmu Pengetahuan Indonesia (LIPI), Samarinda

Nooteboom G, De Jong EBP (2010) Against 'Green development fantasies': resource degradation and the lack of community resistance in the middle Mahakam wetlands, East Kalimantan, Indonesia. Asian J Soc Sci 38:258-278

Page SE, Siegert F, Rieley JO, Boehm H-DV, Jayak A, Limink S (2002) The amount of carbon released from peat and forest fires in Indonesia during 1997. Nature 302:295-301

Persero PT. Virama Karya and PT. Indra Karya (Persero) (2001/2002) Ringkasan Laporan Akhir. Pekerjaan: Penyusunan Masterplan Sungai Mahakam. Pemerintah Propinsi Kalimantan Timur, Dinas Pekerjaan Umum dan Permukiman Prasarana Wilayah, Proyek Pengendalian Banjir dan Pengamanan Pantai Kalimantan Timur, Samarinda, Indonesia

Phillips VD (1998) Peatswamp ecology and sustainable development in Borneo. Biodivers Conserv 7:651-671

Rieley JO, Page SE, Limin SH, Winarti S (1997) The peatland resource of Indonesia and the Kalimantan peat swamp forest research project. In: Rieley JO, Page SE (eds) Biodiversity and sustainability of tropical peatlands. Samara Publishing, Cardigan, pp 37-44

Shephard PA, Rieley JO, Page SE (1997) The relationship between forest vegetation and peat characteristics in the upper catchment of Sungai Sebangau, Central Kalimantan. In: Rieley JO, Page SE (eds)
Biodiversity and Sustainability of Tropical Peatlands. Samara Publishing, Cardigan, pp 191-210

Sumaryono (2005) Protecting The Mahakam Lakes in East kalimantan Through An Eco-Regional Development Program For Sustainable Livelihoods, Paper presented at the 10th Living Lakes Conference, 15-19 May at Tagaytay City, Philippines

Suryadiputra NNC, Gönner P, Wibowo, Ratnawati E (2000) The Mahakam Lakes. Paper presented at the Global Nature Fund Conference, June 16-17, 2000, Hannover, Germany

Suyanto S, Applegate G, Permana RP, Khususiyah N, Kurniawan I (2004) The role of fire in changing land use and livelihoods in Riau-Sumatra. Ecol Soc 9:1-11

United Nations Environment Programme [UNEP] (2006) Protecting the Mahakam Lakes and Wetlands in East Kalimantan through Integrated/Participatory Spatial Planning and Management. Medium Sized Project Proposal Request for GEF Funding, Nairobi, Kenya

US-EPA [United States Environmental Protection Agency] (2009) National Recommend Water Quality Criteria. Office of Water, Office of Science and Technology. Available via: http://water.epa. gov/scitech/swguidance/standards/current/upload/nrwqc-2009.pdf

Weidemann D (2002) Development and extension of a Fire Danger Rating System for the province of East Kalimantan, Indonesia. Final Report, GTZ-MoFEC Integrated Forest Fire Management Project, Samarinda, East Kalimantan

Winkler LW (1888) Die Bestimmung das in Wasser gelosten Sauerstoffen. Ber Dtsch Chem Ges 21:2842-2855

WWF [World Wildlife Foundation] (2005) Borneo: Treasure island at risk. status of forests, wildlife and related threats on the island of Borneo. WWF, Frankfurt am Main, Germany

Zweig RD, Morton JD, Stewart MM (1999) Source water quality for aquaculture - A guide for assessment. World Bank, Washington D.C., USA. Available via: http://www-wds.worldbank.org/ external/default/main? page $P K=64193027$ \& pi $P K=$ $64187937 \&$ the Site P K = 523679\&menu P K= $64187510 \&$ searchMenuPK $=64187283 \&$ siteName $=$ WDS\&entityID=000094946_02030704010886 